\title{
Cu(II) Propionyl-Thiazole Thiosemicarbazone Complexes: Crystal Structure, Inhibition of Human Topoisomerase II $\alpha$, and Activity against Breast Cancer Cells
}

\section{Edward C. Lisic1*, Victoria G. Rand1, Lana Ngo1, Patrick Kent², Jeffrey Rice², Deidra Gerlach ${ }^{3}$, Elizabeth T. Papish ${ }^{3}$, Xiaohua Jiang ${ }^{1}$}

${ }^{1}$ Department of Chemistry, Tennessee Technological University, Cookeville, TN, USA

${ }^{2}$ Department of Chemical Engineering, Tennessee Technological University, Cookeville, TN, USA

${ }^{3}$ Department of Chemistry, The University of Alabama, Tuscaloosa, Alabama, USA

Email: *edlisic@tntech.edu

How to cite this paper: Lisic, E.C., Rand, V.G., Ngo, L., Kent, P., Rice, J., Gerlach, D., Papish, E.T. and Jiang, X.H. (2018) $\mathrm{Cu}(\mathrm{II})$ Propionyl-Thiazole Thiosemicarbazone Complexes: Crystal Structure, Inhibition of Human Topoisomerase II $\alpha$, and Activity against Breast Cancer Cells. Open Journal of Medicinal Chemistry, 8, 30-46. https://doi.org/10.4236/ojmc.2018.82004

Received: May 4, 2018

Accepted: June 26, 2018

Published: June 29, 2018

Copyright $\odot 2018$ by authors and Scientific Research Publishing Inc. This work is licensed under the Creative Commons Attribution International License (CC BY 4.0).

http://creativecommons.org/licenses/by/4.0/

\begin{abstract}
Two new thiosemicarbazone ligands, 2-propionylthiazole ethylthiosemicarbazone (PTZ-ETSC), and 2-propionylthiazole tert-butylthiosemicarbazone (PTZ-tBTSC), along with their two copper(II) complexes, [Cu(PTZ-ETSC)Cl] and $[\mathrm{Cu}(\mathrm{PTZ}-\mathrm{tBTSC}) \mathrm{Cl}]$, are reported here for the first time. Once characterized by NMR and MS, these mono-anionic tridentate ligands were reacted with $\mathrm{Cu}^{2+}$ to form the square planar metal complexes [Cu(PTZ-ETSC)Cl] and [Cu(PTZ-tBTSC)Cl]. The x-ray crystal structure of the [ $\mathrm{Cu}$ (PTZ-tBTSC)Cl] complex shows that the complex adopts a square planar arrangement around the copper(II) ion, but forms a sulfur-bridged dimer in the solid state. Both of the copper complexes displayed strong inhibition of human topoisomerase II $\alpha$ at activities between $2-4 \mu \mathrm{M}$ for [Cu(PTZ-ETSC)Cl], and between $8-10 \mu \mathrm{M}$ for the [Cu(PTZ-tBTSC)Cl] complex. The EC50 values for the MDA-MB-231 breast cancer cell line were $82.6 \mu \mathrm{M}$ for (PTZ-ETSC), $17.9 \mu \mathrm{M}$ for [Cu(PTZETSC)Cl], $97.8 \mu \mathrm{M}$ for (PTZ-tBTSC), and $1.41 \mu \mathrm{M}$ for [Cu(PTZ-tBTSC)Cl]. The EC50 values for the MCF7 breast cancer cell lines were $9.36 \mu \mathrm{M}$ for (PTZ-ETSC), $0.13 \mu \mathrm{M}$ for [Cu(PTZ-ETSC)Cl], $0.333 \mu \mathrm{M}$ for (PTZ-tBTSC), and $0.093 \mu \mathrm{M}$ for $[\mathrm{Cu}(\mathrm{PTZ}-\mathrm{tBTSC}) \mathrm{Cl}]$.
\end{abstract}

\section{Keywords}

Topoisomerase, Breast Cancer, Thiosemicarbazones 


\section{Introduction}

Thiosemicarbazones are exceptionally versatile multidentate ligands that coordinate to many transition metals with hundreds of papers in the literature discussing their biological activities, their analytical uses, and their ability to coordinate transition metal ions in a variety of oxidation states and geometries [1] [2] [3] [4] [5]. Thiosemicarbazones often act as high affinity bidentate, tridentate, or tetradentate chelating agents depending upon their structural backbone, often losing a hydrazinic proton during chelation to become mono-anionic [1] [6] [7].

Interestingly, a specific subset of tridentate thiosemicarbazone ligands that have been referred to as $\alpha$-(N)-heterocyclic thiosemicarbazones have extremely powerful anti-proliferative properties against a wide variety of microbes and cancer cells [8] [9] [10]. Some of these $\alpha$-(N)-heterocyclic thiosemicarbazones, such as Triapine ${ }^{\circledR}$, have potent activity against the enzyme ribonucleotide reductase which catalyzes the conversion of ribonucleotides into deoxyribonucleotides, providing the precursors required for DNA synthesis when a cell is dividing [11] [12] [13]. With their N-N-S tridentate coordination backbone, these $\alpha$-N-heterocyclic thiosemicarbazones have been shown to chelate to biologically important transition metals, such as $\mathrm{Cu}$ (II) and Fe(II) [14] [15] [16] [17]. Coincidentally, literature shows that the copper complexes of several series of tridentate mono-anionic $\alpha$ - $(\mathrm{N})$-heterocyclic thiosemicarbazones are now known to also exhibit greater antineoplastic activity and work by an entirely different mechanism than the ligands themselves [18] [19] [20].

Several series of these $\mathrm{Cu}$ (II) complexes of $\alpha$-(N)-heterocyclic thiosemicarbazones including acetylpyridine-thiosemicarbazones, acetylpyrazine-thiosemicarbazones, as well as benzoylpyridine-thiosemicarbazones, have been demonstrated to have high activity against cancer cell lines due to inhibition of the human topoisomerase II $\alpha$ enzyme [21] [22]. The structural similarity in these three different series of $\mathrm{Cu}$ complexes is that they exhibit a slightly distorted square-planar geometry around the metal center, and have a general formula $[\mathrm{Cu}(\mathrm{TSC}) \mathrm{Cl}]$ [19].

This work expands upon that type research by introducing a previously unknown series of $\alpha$ - $(\mathrm{N})$-heterocyclic thiosemicarbazones ligands based on a 2-propionyl-thiazole backbone, and their $\mathrm{Cu}$ (II) complexes, and shows that the $\mathrm{Cu}$ complexes not only inhibit function of human topoisomerase II $\alpha$, but have significant activity against two different breast cancer cell lines. The structural representations for these new compounds are shown in Figure 1.

\section{Experimental}

\subsection{Material and Methods}

All reagents and solvents used to synthesize the ligands and the copper complexes were purchased from Sigma-Aldrich or Alfa-Aesar and used without further preparation unless otherwise noted. Recombinant human Topoisomerase 
<smiles>CCNC(=S)N(N)/N=C(\CC)c1nccs1</smiles>

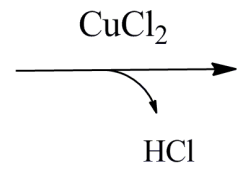<smiles>CC/C(=N\NC(=S)N(C)C(C)(C)C)c1nccs1</smiles>

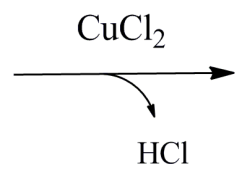

[3] [Cu(PTZ-ETSC)Cl]<smiles>CCNC1=NN2C(CC)=C(Cl)C(Cl)(S1)N2C=CS</smiles>

[4] [Cu(PTZ-tBTSC)Cl]<smiles>CCC1=NN=C(NC(C)(C)C)SC1(Cl)Cl</smiles>

Figure 1. The Propionyl-thiazole-TSC Ligands and the reaction to form their Copper (II) Complexes.

II $\alpha$ was overexpressed and purified from yeast Saccharomyces cervisiae as described [23]. The enzyme was stored in the buffer with $50 \mathrm{mM}$ Tris (pH7.8), 750 $\mathrm{mM} \mathrm{KCl}, 40 \%$ Glycerol and $0.5 \mathrm{mM}$ DTT as $1 \mathrm{mg} / \mathrm{mL}$ stock in liquid nitrogen. Recombinant pBR322 plasmid was amplified and purified following the protocol of Qiagen $^{\text {mi }}$ Plasmid Mega Kit.

\subsection{Instrumentation}

The melting points were taken with a Stanford Research Systems Digimelt MPA160, and TLCs were taken with Whatman $250 \mu \mathrm{m}$ layer PE SIL G/UV polyester-backed plates. The thiosemicarbazone ligands were characterized by ${ }^{1} \mathrm{H},{ }^{13} \mathrm{C}$ DEPTQ-135, ${ }^{1} \mathrm{H}-{ }^{1} \mathrm{H}$ COSY, ${ }^{1} \mathrm{H}^{13} \mathrm{C}$ HSQC, ${ }^{1} \mathrm{H}_{-}-{ }^{15} \mathrm{~N}$ HSQC, ${ }^{1} \mathrm{H}_{-}{ }^{13} \mathrm{C}$ HMBC, and ${ }^{1} \mathrm{H}^{-15} \mathrm{~N}$ HMBC NMR techniques as well as mass spec. NMR spectroscopy was carried out at the Center for Structural Chemistry, Tennessee Technological University (USA). The spectra reported here were measured with a Bruker Avance III HD 500 spectrometer at $500.13 \mathrm{MHz}\left({ }^{1} \mathrm{H}\right), 50.69 \mathrm{MHz}$ $\left({ }^{15} \mathrm{~N}\right)$ and $125.03 \mathrm{MHz}\left({ }^{13} \mathrm{C}\right)$ at $25^{\circ} \mathrm{C}$ equipped with a PRODIGY cryoprobe. For these measurements, the substances were dissolved in the appropriate deuterated solvent, and the chemical shifts were referenced to the solvent residual peak. 
Coupling constants (J) are given in Hertz. The ${ }^{1} \mathrm{H}$ NMR experiments were acquired using Bruker's standard PROTON (zg30) NMR pulse sequence with the following parameters: Relaxation delay, $1 \mathrm{~s} ; 90^{\circ}$ pulse, $12.0 \mu \mathrm{s}$; spectral width, $10,000 \mathrm{~Hz}$; number of data points, $32 \mathrm{~K}$; and digital resolution, $0.153 \mathrm{~Hz} /$ point. The UV-Vis data was gathered using a Cary Varian 3E UV-Vis Spectrophotometer. Each sample was diluted to $10 \mathrm{ppm}$ and scanned over a range of $200-800$ nm. All mass spectrometry data was taken with a Varian 300/310/320-MS LC/MS Quadrupole Mass Spectrometer in negative mode using APCI. The corona current was set to $-5.00 \mu \mathrm{A}$, while the shield potential was set to -600.00 volts. The housing, drying gas, and vaporizer gas temperatures were set to $50^{\circ} \mathrm{C}$, $150^{\circ} \mathrm{C}$, and $350^{\circ} \mathrm{C}$ respectively. The drying, nebulizing, and vaporizer gas pressures were each set to $12.0 \mathrm{psi}, 55.0 \mathrm{psi}$, and $17.0 \mathrm{psi}$. For the mass spectrometry data, each sample was dissolved in minimal amounts of dimethyl sulfoxide and then diluted to $10 \mathrm{ppm}$ in methanol.

\subsection{Synthesis and Characterization}

All reagents and solvents used to synthesize the ligands and the copper complexes were purchased from Sigma-Aldrich or Alfa-Aesar and used without further preparation unless otherwise noted.

\subsubsection{Synthesis of PTZ Ligands}

\section{PTZ-ETSC:}

(E) -N-ethyl-2-[1-(thiazol-2-yI)-propylidene] hydrazinecarbothioamide.

In a $50 \mathrm{ml}$ round-bottomed flask containing a magnetic stir bar was added $1.045 \mathrm{~g}(7.40 \mathrm{mmol})$ of 2-propionylthiazole and $0.8810 \mathrm{~g}(7.39 \mathrm{mmol})$ of 4-ethyl3-thiosemicarbazide. The reagents were dissolved in $30 \mathrm{~mL}$ of isopropanol, and 5 $\mathrm{mL}$ of a $1 \%$ by weight sulfuric acid solution in isopropanol was added to catalyze the reaction. The reaction mixture was heated to $60^{\circ} \mathrm{C}$ and stirred for 24 hours. The solution was cooled to $0^{\circ} \mathrm{C}$ overnight. The white crystalline precipitate formed was filtered and dried. Yield: $1.530 \mathrm{~g}(6.31 \mathrm{mmol}), 85.4 \%$. MP: $137.6^{\circ} \mathrm{C}$. Theoretical MS $\mathrm{m} / \mathrm{z}$ (relative intensity) for $[1]-\mathrm{H}^{+}: 241.06$ (100\%). Actual MS $\mathrm{m} / \mathrm{z}$ (relative intensity) for [1]- $\mathrm{H}^{+}: 241.0(100 \%)$.

H-Bonded Conformer: ${ }^{1} \mathrm{H}$ NMR $\left(500 \mathrm{MHz}\right.$, DMSO- $\left.d_{6}\right) \delta 13.30(\mathrm{~s}, 1 \mathrm{H}$, hydrazinic), $8.69(\mathrm{t}, J=6.0 \mathrm{~Hz}, 1 \mathrm{H}$, thioamide), $8.25(\mathrm{~d}, J=3.3 \mathrm{~Hz}, 1 \mathrm{H}), 8.09$ (d, $J=3.3$ $\mathrm{Hz}, 1 \mathrm{H}), 3.65-3.57(\mathrm{~m}, 2 \mathrm{H}), 3.01(\mathrm{q}, J=7.5 \mathrm{~Hz}, 3 \mathrm{H}), 1.27(\mathrm{t}, J=7.4 \mathrm{~Hz}, 3 \mathrm{H}) 1.16$ (t, $J=7.1 \mathrm{~Hz}, 3 \mathrm{H})$.

Non-H-Bonded Conformer: ${ }^{1} \mathrm{H}$ NMR (500 MHz, DMSO- $\left.d_{6}\right) 10.78$ (s, $1 \mathrm{H}$, hydrazinic), $8.23(\mathrm{t}, J=6.0 \mathrm{~Hz}, 1 \mathrm{H}$, thioamide), $7.88(\mathrm{~d}, J=3.2 \mathrm{~Hz}, 1 \mathrm{H}), 7.78(\mathrm{~d}, J=$ $3.2 \mathrm{~Hz}, 1 \mathrm{H}), 3.65-3.57(\mathrm{~m}, 2 \mathrm{H}), 2.78(\mathrm{q}, J=7.4 \mathrm{~Hz}, 2 \mathrm{H}), 1.15(\mathrm{t}, J=7.1 \mathrm{~Hz}, 3 \mathrm{H})$, $1.06(\mathrm{t}, J=7.5 \mathrm{~Hz}, 3 \mathrm{H})$.

Ratio of H-Bonded Conformer/Non-H-Bonded Conformer at 1 hour (35/1) and at 24 hours $(2.5 / 1)$.

PTZ-tBTSC:

(E) -N-tert-butyl-2-[1-(thiazol-2-yI)-propylidene] hydrazinecarbothioamide 
In a $50 \mathrm{ml}$ round-bottomed flask containing a magnetic stir bar was added $1.071 \mathrm{~g}(7.58 \mathrm{mmol})$ of 2-propionylthiazole and $1.1463 \mathrm{~g}(7.57 \mathrm{mmol})$ of 4-tertbutyl-3-thiosemicarbazide. The reagents were dissolved in $30 \mathrm{~mL}$ of isopropanol, and $5 \mathrm{~mL}$ of a $1 \%$ by weight sulfuric acid solution in isopropanol was added to catalyze the reaction. The reaction mixture was heated to $60^{\circ} \mathrm{C}$ and stirred for 24 hours. The solution was cooled to $0^{\circ} \mathrm{C}$ overnight. The white crystalline precipitate formed was filtered and dried. Yield: $1.430 \mathrm{~g}(5.29 \mathrm{mmol})$, 69.8\%. MP: $135.7^{\circ} \mathrm{C}$. Theoretical MS $\mathrm{m} / z$ (relative intensity): 269.09 (100\%). Actual MS $m / z$ (relative intensity): 269.0 (100\%).

$\mathrm{H}$-Bonded conformer: ${ }^{1} \mathrm{H}$ NMR (500 MHz, DMSO) ${ }^{1} \mathrm{H}$ NMR (500 MHz, DMSO) $\delta 13.22$ (s, $1 \mathrm{H}$, hydrazinic), $8.26(\mathrm{~d}, J=3.2 \mathrm{~Hz}, 1 \mathrm{H}), 8.10(\mathrm{~d}, J=3.2 \mathrm{~Hz}$, $1 \mathrm{H}), 7.89$ (s, 1H, thioamide), 2.80 (q, J= $7.3 \mathrm{~Hz}, 1 \mathrm{H}), 1.53(\mathrm{~s}, 1 \mathrm{H}), 1.24(\mathrm{t}, J=7.3$ $\mathrm{Hz}, 1 \mathrm{H})$.

Non-H-Bonded conformer: ${ }^{1} \mathrm{H}$ NMR (500 MHz, DMSO) 10.84 (s, 1H, hydrazinic), 7.89 (d, $J=3.2 \mathrm{~Hz}, 1 \mathrm{H}), 7.76(\mathrm{~d}, J=3.2 \mathrm{~Hz}, 1 \mathrm{H}), 7.76$ (s, 1H, thioamide), $2.99(\mathrm{q}, J=7.5 \mathrm{~Hz}, 1 \mathrm{H}), 1.54(\mathrm{~s}, 1 \mathrm{H}), 1.07$ (t, $J=7.5 \mathrm{~Hz}, 1 \mathrm{H})$.

Ratio of H-Bonded Conformer/ Non-H-Bonded Conformer at 1 hour (7.6/1) and at 24 hours $(1 / 1.68)$.

\subsubsection{Synthesis of Copper Complexes}

[Cu(PTZ-ETSC)Cl]

Chloro-[ $N$-ethyl-2-[1-(thiazol-2-yl- $\left.\mathrm{N}^{1}{ }^{1}\right)$-propylidene] hydrazinecarbothioamidato$\left.\kappa N^{2}, \kappa S\right]$-copper $(I I)$

The $[\mathrm{Cu}(\mathrm{PTZ}-\mathrm{ETSC}) \mathrm{Cl}]$ complex was synthesized by the same procedure as used for the $[\mathrm{Cu}(\mathrm{PTZ}-\mathrm{tBTSC}) \mathrm{Cl}]$ complex below. Yield: (56.6\%), TLC Silica/ethyl acetate $\left(\mathrm{R}_{\mathrm{f}}\right): 0.91$, Theoretical MS $\mathrm{m} / z$ (relative intensity) for $[3]^{-}: 338.96$ (100\%), 340.95 (85.6\%). Actual MS $\mathrm{m} / z$ (relative intensity): 338.7 (100\%), 340.9 (84.5\%).

Anal. Found: C, 31.55; H, 3.79. Calcd. for $\mathrm{C}_{9} \mathrm{H}_{13} \mathrm{ClCuN}_{4} \mathrm{~S}_{2}$ : C, 31.76; H, 3.85 . UV-VIS: $\lambda_{\max }, \mathrm{nm}(\varepsilon): 421(30.85), 23,753 \mathrm{~cm}^{-1}, 683(0.6115), 14,641 \mathrm{~cm}^{-1}$.

\section{[Cu(PTZ-tBTSC)Cl]}

Chloro-[ $N$-tert-butyl-2-[1-(2-thiazol-2-yl- $\left.\kappa N^{1}\right)$ propylidene] hydrazinecarbothioamidato- $\left.\kappa N^{2}, \kappa S\right]$-copper $(I I)$

In a $100 \mathrm{~mL}$ round-bottomed flask containing a magnetic stir bar was added $0.3234 \mathrm{~g}$ ( $1.90 \mathrm{mmol})$ of copper (II) chloride dihydrate. This was dissolved in 25 $\mathrm{mL}$ of ethanol with stirring, and then $0.5150 \mathrm{~g}(1.90 \mathrm{mmol})$ of 2-propionylthiazole tert-butylthiosemicarbazone (PTZ-tBTSC) which was slurried in $30 \mathrm{~mL}$ of ethanol was added to the flask to initiate the reaction. An immediate dark green color was produced. A reflux condenser was added to the flask and it was heated at 65 degrees Celsius overnight. The dark green solution was filtered hot, and the resulting solution was allowed to cool. The flask was capped and placed in the refrigerator for four days yielding the crystals used to obtain the crystal structure.

Yield: $0.512 \mathrm{~g}(1.39 \mathrm{mmol}),(73.1 \%)$. TLC Silica/ethyl acetate $\left(\mathrm{R}_{\mathrm{f}}\right): 0.90$. Theo- 
retical MS $\mathrm{m} / \mathrm{z}$ (relative intensity): (100\%). Actual MS $\mathrm{m} / \mathrm{z}$ (relative intensity): 366.8 (100\%), 368.2 (43.3\%). Anal. Found: C, 35.55; H, 4.79; Calcd. for $\mathrm{C}_{11} \mathrm{H}_{17} \mathrm{ClCuN}_{4} \mathrm{~S}_{2}: \mathrm{C}, 35.86 ; \mathrm{H}, 4.65$. UV-VIS: $\lambda_{\max }, \mathrm{nm}(\varepsilon): 423$ (35.11), 23,640 $\mathrm{cm}^{-1}, 684(0.6340), 14,620 \mathrm{~cm}^{-1}$.

\subsection{Crystallographic Data Collection and Structure Determination}

Black block crystals of [Cu(PTZ-tBTSC)Cl] were grown from a methanol solution of the compound with cooling. A crystal of dimensions $0.08 \times 0.09 \times 0.10$ $\mathrm{mm}$ was mounted on glass filament with silicone grease a Bruker Apex2 CCD-based X-ray diffractometer equipped with an Oxford N-Helix Cryosystem and fine focus Mo-target X-ray tube $(\lambda=0.71073 \AA)$ operated at $2000 \mathrm{~W}$ power $(50 \mathrm{kV}, 40 \mathrm{~mA})$. The X-ray intensities were measured at 173(2) K; the detector was placed at a distance $6.000 \mathrm{~cm}$ from the crystal. A total of 5002 frames were collected. The total exposure time was 13.89 hours. The frames were integrated with the Saint software package using a narrow-frame algorithm. The integration of the data using a triclinic unit cell yielded a total of 44,474 reflections to a maximum $\theta$ angle of $34.97^{\circ}$ ( $0.62 \AA$ resolution). The final cell constants of $\mathrm{a}=$ $7.9302(2) \AA, \mathrm{b}=8.9315(2) \AA, \mathrm{c}=12.0625(3) \AA, \alpha=105.3380(11)^{\circ}, \beta=$ $101.3206(11)^{\circ}, \gamma=108.2728(11)^{\circ}$, volume $=745.14(5) \AA^{3}$, are based upon the refinement of the xyz-centroids of 9673 reflections above $20 \sigma(\mathrm{I})$ with $5.158^{\circ}<2 \theta$ $<69.79^{\circ}$. Data were corrected for absorption effects using the multi-scan method in SADABS. The space group was assigned as triclinic P-1 using XPREP of the Bruker ShelXTL package, solved with ShelXT and refined with ShelXL 2014/7 and the graphical interface ShelXle, with $\mathrm{Z}=1$ for the formula $\mathrm{C}_{22} \mathrm{H}_{34} \mathrm{~N}_{8} \mathrm{~S}_{4} \mathrm{Cl}_{2} \mathrm{Cu}_{2}$ where the asymmetrical unit $\mathrm{C}_{11} \mathrm{H}_{17} \mathrm{~N}_{4} \mathrm{~S}_{2} \mathrm{ClCu}$ dimerizes across an inversion center [24]. All non-hydrogen atoms were refined anisotropically. $\mathrm{H}$ atoms attached to carbon and nitrogen were positioned geometrically and constrained to ride on their parent atoms. $U_{\text {iso }}(H)$ values were set to a multiple of $U_{\text {eq }}(C)$ with 1.5 for $\mathrm{CH}_{3}$, and $\mathrm{U}_{\text {iso }}(\mathrm{H})$ values were set to a multiple of $\mathrm{U}_{\mathrm{eq}}(\mathrm{C})$ and $\mathrm{U}_{\mathrm{eq}}(\mathrm{N})$ with 1.2 for $\mathrm{CH}_{2}, \mathrm{CH}$, and $\mathrm{NH}$, respectively. Full matrix least-squares refinement based on $\mathrm{F} 2$ converged at $\mathrm{R} 1=0.0210$ and $\mathrm{wR} 2=0.0542$ [based on $\mathrm{I}>2 \sigma(\mathrm{I})$ ], $\mathrm{R} 1=0.0205$ and $\mathrm{wR} 2=0.0563$ for all data. Complete crystallographic data, in CIF format, have been deposited with the Cambridge Crystallographic Data Centre. CCDC $1,560,749$ contains the supplementary crystallographic data for this paper. These data can be obtained free of charge from The Cambridge Crystallographic Data Centre via https://www.ccdc.cam.ac.uk/structures/.

\subsection{TopoII $\alpha$ Mediated Relaxation Assay}

The assay has been described previously [21] [22]. A 20-ul reaction is set up with $0.2 \mu \mathrm{g}$ of TopoII $\alpha, 0.3 \mu \mathrm{g}$ of DNA pBR322, $2 \mathrm{mM}$ ATP and DMSO (ND) or different concentrations $(1-10 \mu \mathrm{M})$ of thiosemicarbazone compounds. The reactions were incubated at $37^{\circ} \mathrm{C}$ for $30 \mathrm{~min}$ and terminated by addition of $3 \mu \mathrm{L}$ of stop solution (77.5 mM EDTA, $0.77 \%$ SDS). Then proteinase $\mathrm{K}$ was added to the 
reaction for incubation at $45^{\circ} \mathrm{C}$ for $30 \mathrm{~min}$. The products were subject to electrophoresis in $1 \%$ agarose gel in $1 \mathrm{x}$ TBE buffer. The results were imaged with BioRad Gel Doc XR+ imaging system.

\subsection{Methods for Alamar Blue Viability Assay of Breast Cancer Cells Exposed to Topoisomerase II Inhibitors}

\subsubsection{Cell Culture and Plating}

Cell lines used were MDA-MB-231 (cancerous, epithelial-type human breast adenocarcinoma cells), and MCF-7 (cancerous, epithelial-type human breast adenocarcinoma cells). Adherent cells were cultured in $25 \mathrm{~cm}^{2}$ or $75 \mathrm{~cm}^{2}$ tissue culture flasks within a humidified incubator at $37^{\circ} \mathrm{C}$ and $5 \% \mathrm{CO}_{2}$. DMEM containing L-glutamine (Lonza) supplemented with penicillin/streptomycin and $10 \%$ FBS was used as the complete culture medium. Confluent cells were trypsinized, cell clumps dissociated by gentle pipetting, and split using a 1:10 ratio into fresh flasks containing pre-warmed complete media. Cell counts were performed by staining $100 \mu \mathrm{L}$ of cells with $100 \mu \mathrm{L}$ of trypan blue (Hyclone) and then counted on a hemocytometer. With this number determined, cells were diluted in complete media to a concentration 25,000 cells $/ \mathrm{mL}$, and $200 \mu \mathrm{L} /$ well of a cell solution was added to a 96-well plate using a multichannel pipette. Plated cells were placed in the humidified incubator at $37^{\circ} \mathrm{C}$ and $5 \% \mathrm{CO}_{2}$ to incubate for 24 hr prior to drug addition.

\subsubsection{Viability Assay of the Ligands and Copper Complexes}

After cells were cultured for $24 \mathrm{hr}$, the existing culture media was replaced with complete media containing dilutions of compounds PTZ-ETSC, [Cu(PTZ-ETSC)Cl], PTZ-tBTSC, and [Cu(PTZ-tBTSC)Cl] ranging from $1000 \mu \mathrm{M}$ down to $0.001 \mu \mathrm{M}$. The dilutions were generated using serial dilutions of prepared DMSO stock solutions of $10 \mathrm{mM}$ in ACS-grade DMSO (Fischer) which were stored at $-20^{\circ} \mathrm{C}$ until use. Wells were also prepared with $200 \mu \mathrm{L}$ of complete media only or 200 $\mu \mathrm{L}$ of complete media with 1:100 dilution of DMSO as positive controls. Both positive controls were found to be statistically equivalent showing no added toxicity of DMSO at the highest applied concentration of DMSO. The 96-well plate was then incubated (humidified, $37^{\circ} \mathrm{C}, 5 \% \mathrm{CO}_{2}$ ) for $24 \mathrm{hr}$ after application of the compounds. Alamar Blue (Thermo Scientific) was then added to each well using complete media as a carrier to attain $8 \%$ Alamar blue per well and applied using a multichannel pipette. The plate was then placed back into the incubator and allowed to incubate for approximately $5 \mathrm{hr}$, after which fluorescence measurements were made at $560 \mathrm{~nm}$ excitation and $590 \mathrm{~nm}$ emission using the Tecan infinite M200 Pro reader.

\subsubsection{Data Analysis}

Initial analysis of fluorescence data were performed with Microsoft Excel 2013 normalized by the fluorescence signal from positive controls. Statistical analysis, data fitting, and plot generation was performed with GraphPad Prism 6; norma- 
lized data were fit using $\log$ (inhibitor) vs. response with variable slope (four parameter) model. This model calculated EC50 and Hill slope values for each curve.

\section{Results and Discussion}

\subsection{Synthesis of Ligands and Ligand Conformations in Solution}

The synthesis of the PTZ-ETSC and PTZ-tBTSC ligands proceeds in good yield to produce clean, crystalline off-white solids. These ligands have some solubility in polar organic solvents such as methanol, ethanol, and isopropanol, and are more soluble in acetone and DMSO; but they are not appreciably soluble in water.

These ligands show evidence of two conformers in solution at equilibrium at room temperature as seen by ${ }^{1} \mathrm{H}$ NMR. We have shown this type of equilibrium to be between an intramolecular hydrogen-bonded ( $\mathrm{HB}$ ) form and a non-hydrogen bonded (NHB) form for the analogous ligands ATZ-ETSC and ATZ-tBTSC, which has been recently published [25].

The thiosemicarbazone hydrazinic N-H hydrogen $\mathrm{H}(1)$ appears between 13.30 $\mathrm{ppm}$ and $10.78 \mathrm{ppm}$ in each molecule. Moreover, the HB form of the hydrazinic $\mathrm{H}(1)$ was shifted greatly downfield an average of $2.45 \mathrm{ppm}$ which supports its participation in a hydrogen bond [25]. The hydrazinic proton is the most downfield shifted of all the protons on the HB form, and the further away from the hydrogen bond the protons are on the molecule the lesser they are shifted. The next protons to feel the effect of the hydrogen bond are the thiazole ring protons of which there are two. Signals for the thiazole ring hydrogens were found as two doublets between $8.26 \mathrm{ppm}$ and $7.76 \mathrm{ppm}$ in both the HB and NHB forms. The signals from the $\mathrm{HB}$ form were shifted up field on average $0.37 \mathrm{ppm}$ for $\mathrm{H}(\mathrm{r} 1)$ and $0.32 \mathrm{ppm}$ for $\mathrm{H}(\mathrm{r} 2)$. This is consistent with the data from the ATZ-ETSC and ATZ-tBTSC molecules reported previously which had shifts of $0.38 \mathrm{ppm}$ and $0.31 \mathrm{ppm}$ for the same thiazole ring protons [25]. The thioamide protons reported here $\mathrm{H}(\mathrm{th})$ appear between $7.76 \mathrm{ppm}$ and $8.69 \mathrm{ppm}$. The signal for the $\mathrm{HB}$ form of $\mathrm{H}(\mathrm{th})$ shifted on average $0.30 \mathrm{ppm}$ downfield also supporting the presence of this hydrogen bond. Parts of these molecules that should not experience substantial changes in their chemical environment with the formation of an internal hydrogen bond such as the ethyl hydrogen's and the tert-butyl hydrogen's were shifted an average of $0.01 \mathrm{ppm}$ downfield reinforcing the local nature of these chemical shift changes due to the hydrazinic hydrogen bond.

Thus far the minor and major forms of the series of molecules reported here can be visualized as an internally hydrogen bonded $\mathrm{HB}$ and non-hydrogen bonded NHB hydrazinic $\mathrm{H}$ configurations as shown in Figure 2.

To ascertain the exact form of the major and minor configurations of this series of thiosemicarbazones the nitrogen chemical shifts were examined. This was achieved via ${ }^{1} \mathrm{H}^{-15} \mathrm{~N}$ HSQC and ${ }^{1} \mathrm{H}-{ }^{15} \mathrm{~N}$ HMBC NMR with all nitrogen nuclei being clearly visible in all spectra. 


\section{HB Conformer}

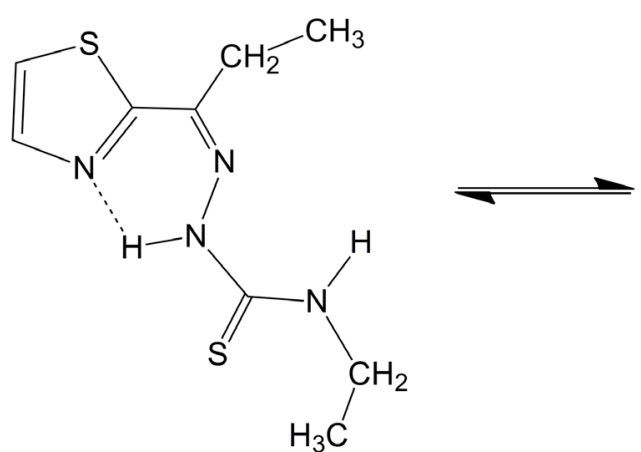

\section{NHB Conformer}<smiles>CCNC(=S)N/N=C(\CC)c1nccs1</smiles>

Figure 2. Hydrogen bonded (HB) and non-hydrogen bonded (NHB) forms of the ligands found in d6-DMSO solvent at ambient temperature.

In this system, the thiazole nitrogen appears between $304 \mathrm{ppm}$ and $312 \mathrm{ppm}$. In the minor form the resonance shifts an average of $4.55 \mathrm{ppm}$ up field. This upfield shift is consistent with the hydrogen bond reducing the $\mathrm{sp}^{2}$ character of and increasing its $\mathrm{sp}^{3}$ character. The protonation of the thiazole ring and resulting resonance stabilized tautomer that would be one of the expected contributing resonance forms of the molecule in the hydrogen bonded conformation.

The two conformations of the PTZ-ETSC and the PTZ-tBTSC ligands are in equilibrium in solution after approximately 12 hours in DMSO, and cannot be isolated. The discerned ratios change from primarily $\mathrm{HB}$ conformation initially in solution (the PTZ-ETSC HB/NHB ratio of 35/1 and PTZ-tBTSC HB/NHB ratio of 7.6/1) to more nearly equal ratios (the PTZ-ETSC HB/NHB ratio of 2.5/1 and PTZ-tBTSC HB/NHB ratio of 1/1.68) of both conformers.

\subsection{Copper Complexes}

The alpha-(N)-heterocyclic thiosemicarbazones chelate metal ions such as $\mathrm{Cu}$ (II) by loss of the hydrazinic proton, which results in a tridentate mono-anionic ligand, and this ligand then becomes planar with apparent resonance stabilization.

The [ $\mathrm{Cu}(\mathrm{PTZ}-\mathrm{tBTSC}) \mathrm{Cl}]$ complex crystallizes as a S-bridged dimeric form, a type that has been reported in the literature for several similar compounds [26] [27]. The dimeric crystal structure of [Cu(PTZ-tBTSC)Cl] is shown in Figure 3.

The $\mathrm{Cu}$ (II) complexes of $\alpha$-(N)-heterocyclic thiosemicarbazones seem to generally crystallize in three fashions, 1 ) as simple square-planar monomers, 2) as S-bridged dimeric structures, and 3) as halide bridged dimers [27]. The reasons for these types of solid state structures existing as monomers or as dimers for $[\mathrm{Cu}(\mathrm{TSC}) \mathrm{Cl}]$ complexes are unknown, but possible contributing factors are the nature of the heterocyclic ring, the bulkiness of substituents on the ring and the thioamide arm [26]-[32].

In the dimer there is $3.482 \AA$ between $\mathrm{Cu}$ centers, which is consistent with reports in the literature of other similar $\mathrm{Cu}(\mathrm{II}) \alpha$-(N)-heterocyclic thiosemicarbazones compounds [27]. It is important to note that the crystal structure is of the 


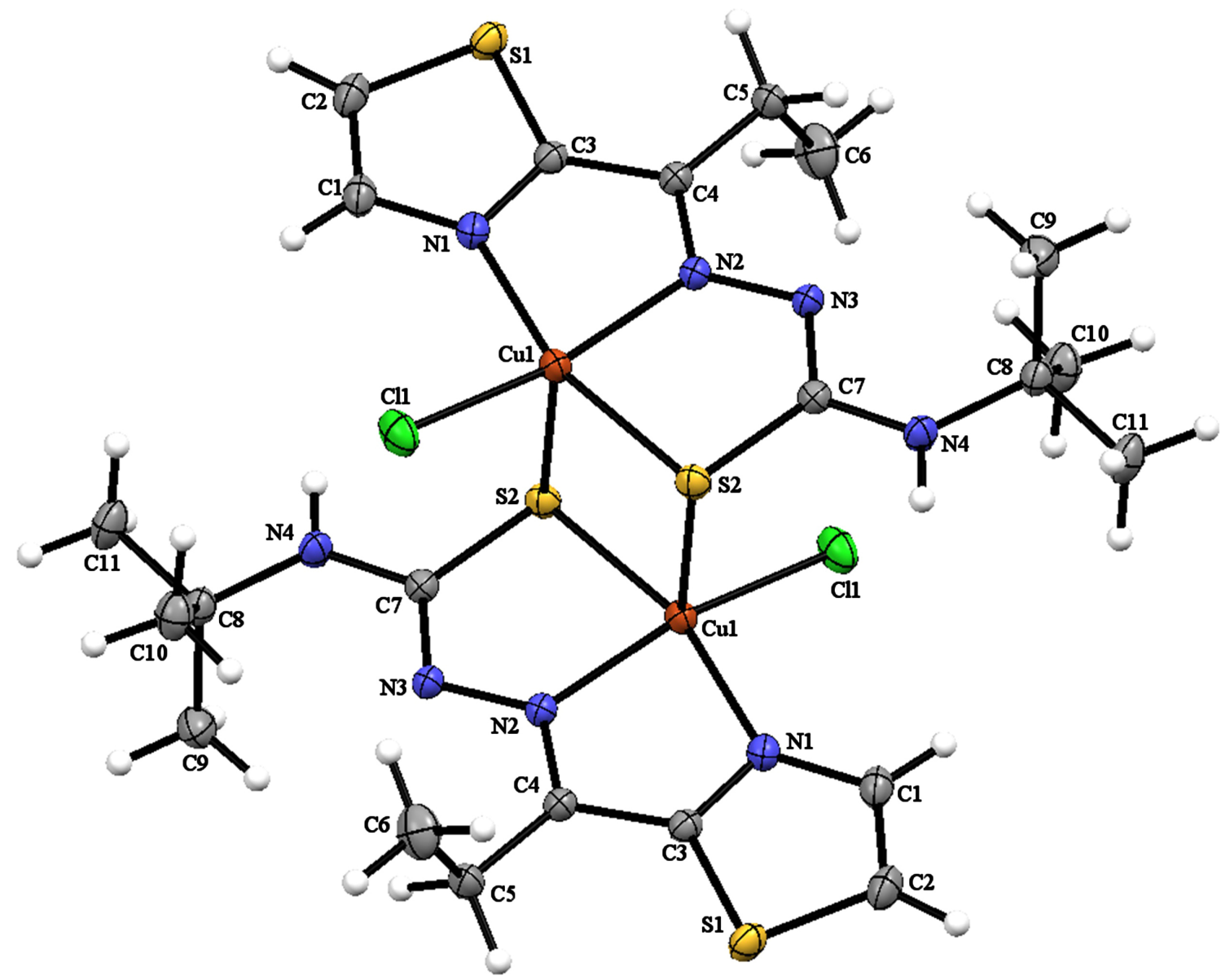

Figure 3. Crystal structure of $[\mathrm{Cu}(\mathrm{PTZ}-\mathrm{tBTSC}) \mathrm{Cl}]$ as a dimer.

solid material, but that the biological work reported in the next sections is on the compounds in solution.

As we and others have noted, the mass spec data shows that the [ $\mathrm{Cu}(\mathrm{TSC}) \mathrm{Cl}]$ compounds are monomers in solution. Thus, the biologically active $\mathrm{Cu}$ (II) species are not dimers, but solvated monomers; we believe that the solution structure of the $[\mathrm{Cu}(\mathrm{PTZ}-\mathrm{ETSC}) \mathrm{Cl}]$ and $[\mathrm{Cu}(\mathrm{PTZ}-\mathrm{tBTSC}) \mathrm{Cl}]$ complexes is indicated by the monomeric structure shown in Figure 4 . This conclusion is backed up by our mass spec data listed in the synthesis section, which shows that the molecular ion in negative APCI mode indicates the monomer is the actual species in solution.

\subsection{The Copper(II) Complexes Inhibit TopoII $\alpha$-Mediated DNA Plasmid Relaxation}

Previous studies have shown that $\mathrm{Cu}(\mathrm{II})$ thiosemicarbazone complexes inhibit TopoII $\alpha$ activities in TopoII $\alpha$-mediated DNA plasmid relaxation assays [21] [22]. We tested [Cu(PTZ-ETSC) $\mathrm{Cl}]$ and [Cu(PTZ-tBTSC)Cl] inhibition on human TopoII $\alpha$, and some of that data is shown in Figure 5.

The ligands PTZ-ETSC and PTZ-tBTSC didn't show any inhibition of the TopoII $\alpha$ enzyme at concentrations less than $50 \mu \mathrm{M}$, and so aren't included in 


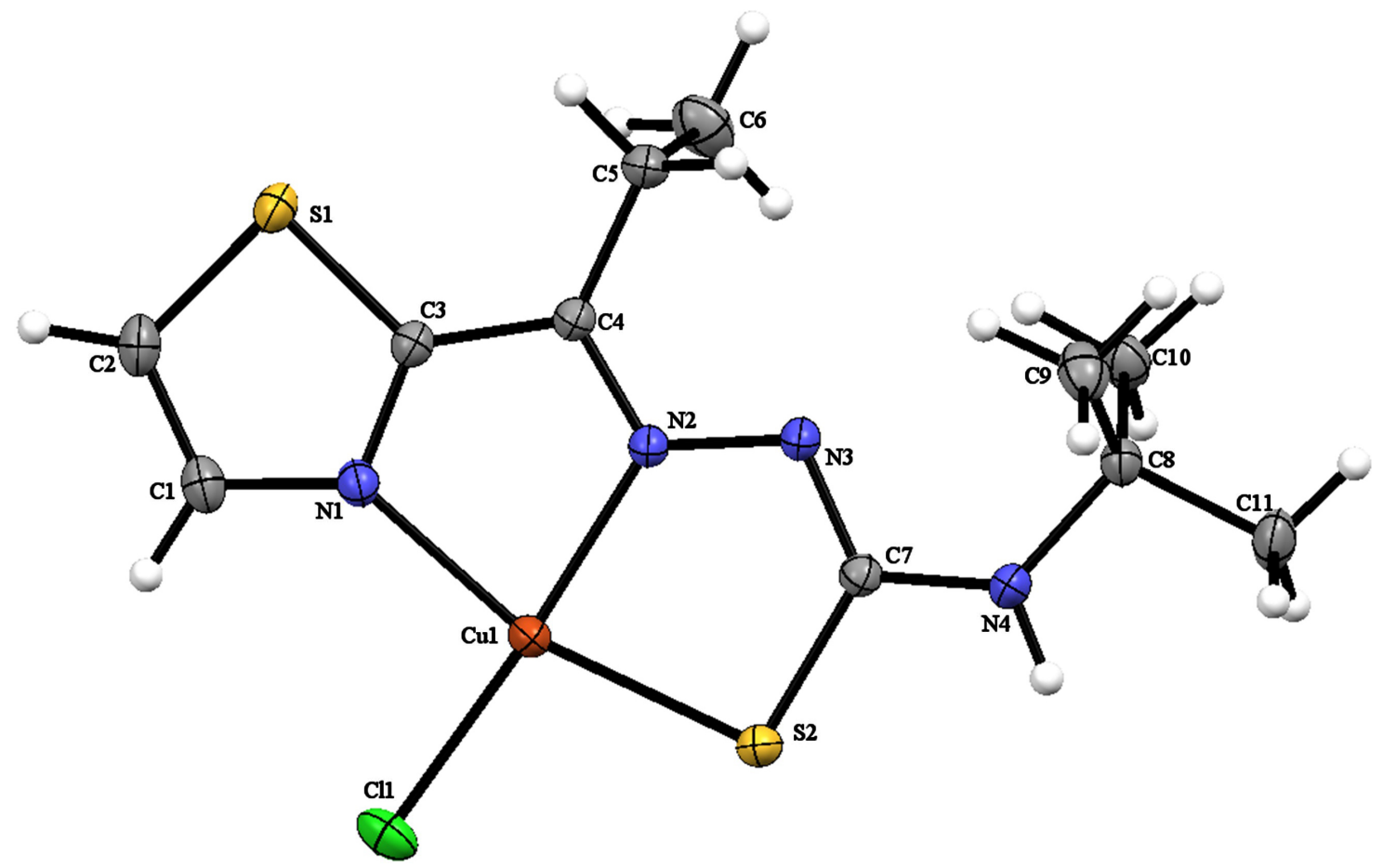

Figure 4. Crystal structure of $[\mathrm{Cu}(\mathrm{PTZ}-\mathrm{tBTSC}) \mathrm{Cl}]$ as a monomer.

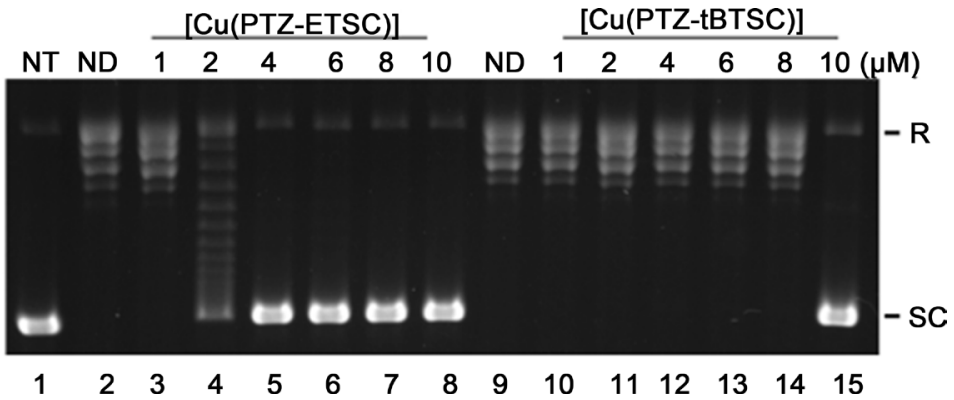

Figure 5. Dose-dependence inhibition of TopoII $\alpha$ by [Cu(PTZ-ETSC)Cl] and [Cu(PTZ-tBTSC)Cl].

Figure 5, however, the dose dependence inhibition of human topoisomerase II $\alpha$ is shown for both of the $\mathrm{Cu}$ (II) complexes compared in this study.

The $[\mathrm{Cu}(\mathrm{PTZ}$-ETSC)Cl] or [ $\mathrm{Cu}$ (PTZ-tBTSC)Cl] metal complexes with concentrations of $1,2,4,6,8$ or $10 \mu \mathrm{M}$ were incubated with TopoII $\alpha$ and pBR322 in the presence of $2 \mathrm{mM}$ ATP. The NT lane is the control without TopoII $\alpha$. ND is the control with $1 \%$ of DMSO, and no TSC drugs. The result here is one representative of four independent experiments. Relaxed (R) DNA and Supercoiled (SC) DNA are denoted on the right on the assay. The SC DNA is relaxed by Topo to form the R DNA, and so the addition of drug causes the Topo inhibition which is revealed by the presence of the SC DNA on that gel lane.

As shown in Figure 5, concentrations of [Cu(PTZ-ETSC)Cl] or [Cu(PTZ-tBTSC)Cl] were examined from $1-10 \mu \mathrm{M}$. The results show that $[\mathrm{Cu}(\mathrm{PTZ}-\mathrm{ETSC}) \mathrm{Cl}]$ inhibits TopoII $\alpha$ at $\sim 2 \mu \mathrm{M}$, while [Cu(PTZ-tBTSC)Cl] inhibits at $\sim 10 \mu \mathrm{M}$. Our data 
suggest that both $[\mathrm{Cu}$ (PTZ-ETSC) $\mathrm{Cl}]$ and $[\mathrm{Cu}$ (PTZ-tBTSC)Cl] exhibit excellent inhibitory activities on TopoII $\alpha$, but that the [Cu(PTZ-ETSC)Cl] complex inhibits Topo at even lower concentrations than does the[Cu(PTZ-tBTSC)Cl].

\subsection{In Vitro Viability Assays}

The in vitro viability assay of compounds PTZ-ETSC, PTZ-tBTSC, [Cu(PTZ-ETSC)Cl)] and $[\mathrm{Cu}(\mathrm{PTZ}-\mathrm{tBTSC}) \mathrm{Cl}]$ was determined using two cancerous, epithelial-type human breast adenocarcinoma cell lines, MDA-MB-231 and MCF7. Compound concentrations ranging from $0.001-1000 \mu \mathrm{M}$ were used and cell viability was assayed after 24 hours of incubation with the compounds in complete DMEM media.

\subsubsection{MDA-MB-231 Assays}

The MDA-MB-231 cells were treated with ligands or copper complexes after a $48 \mathrm{hr}$ recovery time. Then, the cells were allowed to incubate another $24 \mathrm{hr}$ with the inhibitors before assaying with Alamar Blue. Concentration of inhibitors and ligands ranged from $0.001 \mu \mathrm{M}$ to $1000 \mu \mathrm{M}$. All fluorescence data were collected after $4 \mathrm{hr}$ of incubation with Alamar Blue. Each concentration was tested in replicates of 4.

Cells were initially plated at a target density of 5000 cells/well in a 96-well plate. Inhibitors were added to the wells after 48 hours of incubation. Then, the cells were allowed to incubate another 24 hours with the inhibitors before assaying with Alamar Blue. Here, cell viability refers to the fraction of Alamar Blue signal relative to a positive control of healthy (no inhibitor) cells. Viability is proportional to the fluorescence signal from the conversion of Alamar Blue-greater signal means greater viability.

As shown in Figure 6 for one experiment of six of cellular viability using the four new compounds (each experiment had 4 replicates done for each concentration) the most effective compound for activity against the MDA-MB-231 breast cancer cell line was the $[\mathrm{Cu}(\mathrm{PTZ}-\mathrm{tBTSC}) \mathrm{Cl}]$ complex.

The EC50 values for the MDA-MB-231 breast cancer cell line were $82.6 \mu \mathrm{M}$ for (PTZ-ETSC), $17.9 \mu \mathrm{M}$ for [Cu(PTZ-ETSC)Cl], $97.8 \mu \mathrm{M}$ for (PTZ-tBTSC), and $1.41 \mu \mathrm{M}$ for [Cu(PTZ-tBTSC)Cl].

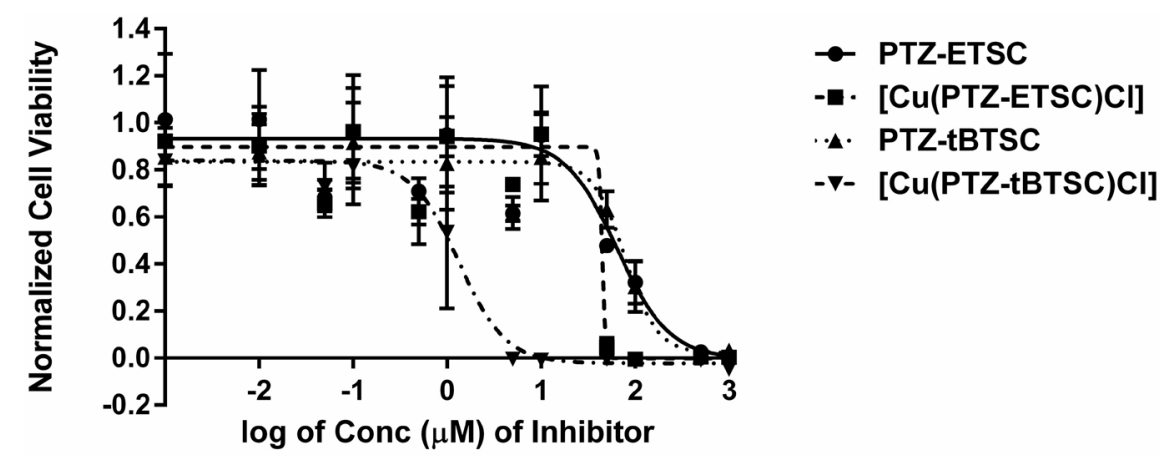

Figure 6. One of the MDA-MB-231 cell viability experiments. 


\subsubsection{MCF-7 Assays}

MCF7 cells were treated with inhibitors and uncomplexed ligands after a $94 \mathrm{hr}$ recovery time. Then, the cells were allowed to incubate another $24 \mathrm{hr}$ with the inhibitors before assaying with Alamar Blue. Concentration of inhibitors and ligands ranged from $0.01 \mu \mathrm{M}$ to $1000 \mu \mathrm{M}$. All fluorescence data were collected after $4 \mathrm{hr}$ of incubation with Alamar Blue. Each concentration was tested in replicates of 4 .

As shown in Figure 7 for one experiment of six of cellular viability using the four new compounds (each experiment had 4 replicates done for each concentration) the most effective compound for activity against the MCF-7 breast cancer cell line was also the [Cu(PTZ-tBTSC)Cl] complex. The EC50 values for the MCF7 breast cancer cell lines were $9.36 \mu \mathrm{M}$ for (PTZ-ETSC), $0.13 \mu \mathrm{M}$ for [Cu(PTZ-ETSC)Cl], $0.333 \mu \mathrm{M}$ for (PTZ-tBTSC), and $0.093 \mu \mathrm{M}$ for [Cu(PTZ-tBTSC)Cl].

\section{Conclusions}

The PTZ-ETSC and the PTZ-tBTSC ligands form two conformers each in the solution state which can best be described as the non-hydrogen-bonded conformer and the hydrogen-bonded conformer. It is not known if the two conformers that are in equilibrium in solution exhibit different biological properties. However, the biological studies presented here show that the PTZ-tBTSC compound has more anti-proliferative action (probably ribonucleotide reductase poisoning, as with Triapine) against both MDA and MCF-7 cancer cell lines studied than its PTZ-ETSC analogue. This could be due to the fact that at equilibrium, the PTZ-tBTSC has a higher ratio of non-hydrogen-bonded conformer than does PTZ-ETSC, however, the tert-butyl group is more lipophilic than the ethyl group, and this difference in lipophilicity may indicate that the PTZ-tBTSC enters the cell more effectively than the PTZ-ETSC.

More importantly, the copper complexes of the ligands are far more effective at inhibition of the Topo enzyme than the ligands themselves, and also inhibit viability of both cancer cell lines more than the ligands. The ligands will not inhibit Topo at concentrations below $50 \mathrm{uM}$, however, the [ $\mathrm{Cu}(\mathrm{PTZ}-\mathrm{tBTSC}) \mathrm{Cl}$ ] complex inhibits Topo at $8-10 \mathrm{uM}$, and the smaller [Cu(PTZ-ETSC)Cl] complex inhibits Topo at lower levels down to $2-4 \mathrm{uM}$. The [Cu(PTZ-ETSC)Cl]

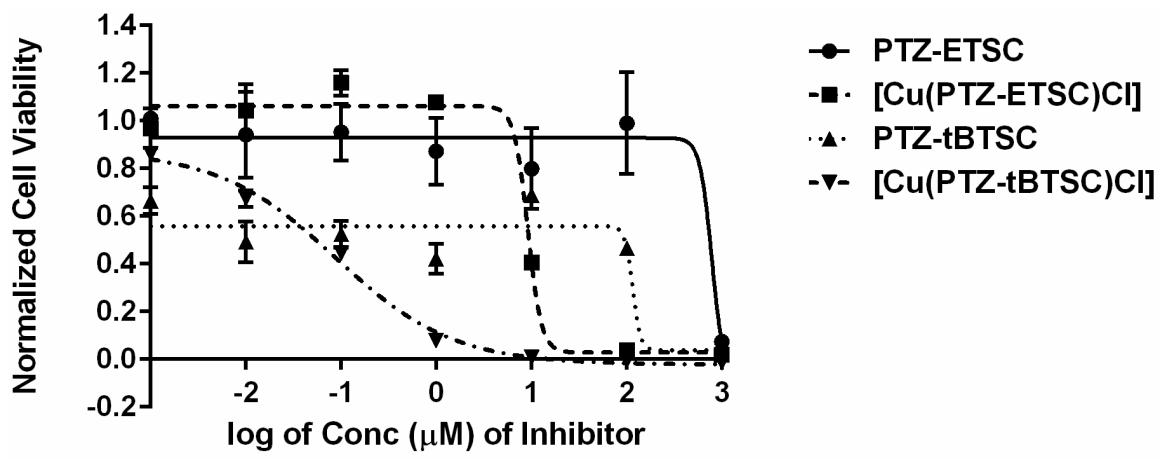

Figure 7. One of the MCF-7 cell viability experiments. 
complex is the better inhibitor of Topo, possibly because it is smaller than the $[\mathrm{Cu}$ (PTZ-tBTSC)Cl] complex and can somehow interact with the Topo with less steric hindrance. However, that is not the case when compared to the breast cancer cell viability assays. For the breast cancer cell lines the larger and more lipophilic [ $\mathrm{Cu}(\mathrm{PTZ}-\mathrm{tBTSC}) \mathrm{Cl}]$ complex is more effective with lower EC50 values. The results may possibly be explained by greater cell permeability of the $[\mathrm{Cu}(\mathrm{PTZ}-\mathrm{tBTSC}) \mathrm{Cl}]$ complex through the cell membranes which equates to more cell bioavailability.

\section{Acknowledgements}

We would like to thank the National Science Foundation for funding the purchase of the FT-NMR used in this research, National Science Foundation (NSF) Major Research Instrument (MRI 1531870) and the URECA! Grant Program at TTU for awarding funds to Ms. Victoria G. Rand to buy necessary supplies and funds to present portions of this research at the April 2017 ACS National Meeting in San Francisco, CA.

\section{References}

[1] Beraldo, H. and Gambino, D. (2004) The Wide Pharmacological Versatility of Semicarbazones, Thiosemicarbazones and Their Metal Complexes. Mini-Rev. Medicinal Chemistry, 4, 31-39. https://doi.org/10.2174/1389557043487484

[2] Brockman, R., Sidwell R., Arnett G. and Shaddix, S. (1970) Heterocyclic Thiosemicarbazones: Correlation between Structure, Inhibition of Ribonucleotide Reductase, and Inhibition of DNA Viruses. Experimental Biology and Medicine, 133, 609-614. https://doi.org/10.3181/00379727-133-34528

[3] Bavin, E.M., Rees, R.J.W., Robson, J.M., Seiler, M., Seymour, D.E. and Suddaby, D. (1950) The Tuberculostatic Activity of Some Thiosemicarbazones. Journal of Pharmacy and Pharmacology, 2, 764-772. https://doi.org/10.1111/j.2042-7158.1951.tb13043.x

[4] Koch, O. and Stuttgen, G. (1950) Clinical and Experimental Studies on the Effects of Thiosemicarbazones. Naunyn-Schmiedebergs Archiv für experimentelle Pathologie und Pharmakologie, 210, 409-423. https://doi.org/10.1007/BF00246392

[5] Kune, G.A. (1964) Today's Drugs: Methisazone. British Medical Journal, 2, 621. https://doi.org/10.1136/bmj.2.5409.621

[6] Padhye, S. and Kauffman, G.B. (1985) Transition Metal Complexes of Semicarbazones and Thiosemicarbazones. Coordination Chemistry Reviews, 63, 127-160. https://doi.org/10.1016/0010-8545(85)80022-9

[7] Casas, J.S., Garcia-Tasende, M.S. and Sordo, J. (2000) Main Group Metal Complexes of Semicarbazones and Thiosemicarbazones. A Structural Review. Coordination Chemistry Reviews, 209, 197-261. https://doi.org/10.1016/S0010-8545(00)00363-5

[8] Yu, Y., Kalinowski, D.S., Kovacevic, Z., Siafakas, A.R., Jansson, P.J., Stefani, C., Lovejoy, D.B., Sharpe, P.C., Bernhardt, P.V. and Richardson, D.R. (2009) Thiosemicarbazones from the Old to New: Iron Chelators That Are More than just Ribonucleotide Reductase Inhibitors. Journal of Medicinal Chemistry, 52, 5271-5294. https://doi.org/10.1021/jm900552r

[9] Matesanz, A. and Souza, P. (2009) $\alpha$-N-Heterocyclic Thiosemicarbazone Derivatives 
as Potential Antitumor Agents: A Structure-Activity Relationship. Mini-Reviews in Medicinal Chemistry, 9, 1389-1396. https://doi.org/10.2174/138955709789957422

[10] Moorthy, N., Cerquiera, N., Ramos, M. and Fernandez, P. (2013) Development of Ribonucleotide Reductase Inhibitor: A Review on Structure Activity Relationships. Mini-Reviews in Medicinal Chemistry, 13, 1-11. https://doi.org/10.2174/13895575113136660090

[11] Finch, R.A., Liu, M., Grill, S.P., Rose, W.C., Loomis, R., Vasquez, K.M., Cheng, Y.C. and Sartorelli, A.C. (2000) Triapine (3-Aminopyridine-2-Carboxaldehyde-Thiosemicarbazone): A Potent Inhibitor of Ribonucleotide Reductase Activity with Broad Spectrum Antitumor Activity. Biochemical Pharmacology, 59, 983-991. https://doi.org/10.1016/S0006-2952(99)00419-0

[12] Knox, J.J., Hotte, S.J., Kollmannsberger, C., Winquist, E., Fisher, B. and Eisenhauer, E.A. (2007) Phase II Study of Triapine ${ }^{\circledR}$ in Patients with Metastatic Renal Cell Carcinoma: A Trial of the National Cancer Institute of Canada Clinical Trials Group (NCIC IND. 161). Investigational New Drugs, 25, 471-477. https://doi.org/10.1007/s10637-007-9044-9

[13] Ma, B., Goh, B.C., Tan, E.H., Lam, K.C., Soo, R., Leong, S. S., et al. (2008) A Multicenter Phase II Trial of 3-Aminopyridine-2-Carboxaldehyde Thiosemicarbazone (3-AP, Triapine ${ }^{\circledR}$ ) and Gemcitabine in Advanced Non-Small-Cell Lung Cancer with Pharmacokinetic Evaluation Using Peripheral Blood Mononuclear Cells. Investigational New Drugs, 26, 169-173. https://doi.org/10.1007/s10637-007-9085-0

[14] West, D.X., Ives, J.S., Krejci, J., Salberg, M.M., Zumbahlen, T.L., Bain, G.A. and Toscano, R.A. (1995) Copper (II) Complexes of 2-Benzoylpyridine ${ }^{4} \mathrm{~N}$-Substituted Thiosemicarbazones. Polyhedron, 14, 2189-2200. https://doi.org/10.1016/0277-5387(95)00010-P

[15] Easmon, J., Puerstinger, G., Heinisch, G., Roth, T., Fiebig, H.H., Holzer, W., Jaeger, W., Jenny, M. and Hofmann, J. (2001) Synthesis, Cytotoxicity, and Antitumor Activity of Copper(II) and Iron(II) Complexes of ${ }^{4} \mathrm{~N}$-Azabicyclo[3.2.2]Nonane Thiosemicarbazones Derived from Acyl Diazines. Journal of Medicinal Chemistry, 44, 2164-2171. https://doi.org/10.1021/jm000979z

[16] Shao, J., Zhou, B., Di Bilio, A.J., Zhu, L., Wang, T., Qi, C., Shih, J. and Yen, Y. (2006) A Ferrous-Triapine Complex Mediates Formation of Reactive Oxygen Species That Inactivate Human Ribonucleotide Reductase. Molecular Cancer Therapeutics, 5, 586-592. https://doi.org/10.1158/1535-7163.MCT-05-0384

[17] Kalinowski, D.S. and Richardson, D.R. (2007) Future of Toxicology iron Chelators and Differing Modes of Action and Toxicity: The Changing Face of Iron Chelation Therapy. Chemical Research in Toxicology, 20, 715-720. https://doi.org/10.1021/tx700039c

[18] Jansson, P.J., Sharpe, P.C., Bernhardt, P.V. and Richardson, D.R. (2010) Novel Thiosemicarbazones of the ApT and DpT Series and Their Copper Complexes: Identification of Pronounced Redox Activity and Characterization of Their Antitumor Activity. Journal of Medicinal Chemistry, 53, 5759-5769. https://doi.org/10.1021/jm100561b

[19] Zeglis, B.M., Divilov, V. and Lewis, J.S. (2011) Role of Metalation in the Topoisomerase II $\alpha$ Inhibition and Antiproliferation Activity of a Series of $\alpha$-HeterocyclicN4-Substituted Thiosemicarbazones and Their $\mathrm{Cu}(\mathrm{II})$ Complexes. Journal of Medicinal Chemistry, 54, 2391-2398. https://doi.org/10.1021/jm101532u

[20] Yalowich, J.C., et al. (2012) The Anticancer Thiosemicarbazones Dp44mT and Tri- 
apine Lack Inhibitory Effects as Catalytic Inhibitors or Poisons of DNA Topoisomerase II $\alpha$. Biochemical Pharmacology, 84, 52-58. https://doi.org/10.1016/j.bcp.2012.03.021

[21] Wilson, J.T., Jiang, X., McGill, B.C., Lisic, E.C. and Deweese, J.E. (2016) Examination of the Impact of Copper(II) $\alpha$-( $N$-Heterocyclic Thiosemicarbazone Complexes on DNA Topoisomerase II $\alpha$. Chemical Research in Toxicology, 29, 649-658. https://doi.org/10.1021/acs.chemrestox.5b00471

[22] Conner, J.D., Medawala, W., Stephens, M.T., Morris, W.H., Deweese, J.E., Kent, P.L., Rice, J.J., Jiang, X. and Lisic, E.C. (2016) Cu(II) Benzoylpyridine Thiosemicarbazone Complexes: Inhibition of Human Topoisomerase II $\alpha$ and Activity against Breast Cancer Cells. Open Journal of Inorganic Chemistry, 6, 146. https://doi.org/10.4236/ojic.2016.62010

[23] Regal, K.M., Mercer, S.L. and Deweese, J.E. (2014) HU-331 Is a Catalytic Inhibitor of Topoisomerase II $\alpha$. Chemical Research in Toxicology, 24, 2044-2051. https://doi.org/10.1021/tx500245m

[24] Sheldrick, G.M. (2008) A Short History of SHELX. Acta Crystallographica Section $A, 64,112-122$. https://doi.org/10.1107/S0108767307043930

[25] Carroll, W.R., Gardner, D.M., Melton, E.R., Murphy, S.T., Buckner, A.K., Fulmer, M.S., Qualls, W.G. and Lisic, E.C. (2018) ${ }^{1} \mathrm{H},{ }^{13} \mathrm{C}$, and ${ }^{15} \mathrm{~N}$ NMR Conformational Characterization of a Series of 2-Acetylthiazolethiosemicarbazone Compounds. Journal of Molecular Structure, 1157, 8-13. https://doi.org/10.1016/j.molstruc.2017.11.061

[26] Qi, J., Liang, S., Gou, Y., Zhang Z., Zhou, Z., Yang, F. and Liang, H. (2015) Synthesis of Four Binuclear Copper(II) Complexes: Structure, Anticancer Properties and Anticancer Mechanism. European Journal of Medicinal Chemistry, 96, 360-368. https://doi.org/10.1016/j.ejmech.2015.04.031

[27] Gil-Garcia, R., Gomez-Saiz, P., Diez-Gomez, V., Madariaga, G., Insausti, M., Lezama, L., Cuevas, J.V. and Garcia-Tojal, J. (2014) Thiosemicarbazonecopper(II) Compounds with Halide/Hexafluorosilicate Anions: Structure, Water Clusters, Non-Covalent Interactions and Magnetism. Polyhedron, 81, 675-686. https://doi.org/10.1016/j.poly.2014.07.032

[28] Naskar, S., Naskar, S., Mayer-Figge, H., Sheldrick, W.S., Corbella, M., Tercero, J. and Chattopadhyay, S.K. (2012) Study of Copper(II) Complexes of Two Diacetyl Monooxime Thiosemicarbazones: X-Ray Crystal Structure and Magneto-Structural Correlation of $\left[\mathrm{Cu}(\mathrm{dmoTSCH}) \mathrm{Cl}_{2} \mathrm{xH}_{2} \mathrm{O}\right.$ (dmoTSCH $=$ Monoanion of Diacetyl Monooxime Thiosemicarbazone). Polyhedron, 97, 157-166.

[29] Garcia, B., Garcia-Tojal, J., Ruiz, R., Gil-Garcia, R., Ibeas, S., Donnadieu, B. and Leal, J.M. (2008) Interaction of the DNA Bases and Their Mononucleotides with Pyridine-2-Carbaldehyde Thiosemicarbazone Copper(II) Complexes. Structure of the Cytosine Derivative. Journal of Inorganic Biochemistry, 102, 1892-1900. https://doi.org/10.1016/j.jinorgbio.2008.06.013

[30] Ilies, Diana-C., Shova, S., Radescu, V., Pahontu, E. and Rosu, T. (2015) Synthesis, Characterization, Crystal Structure and Antioxidant Activity of $\mathrm{Ni}(\mathrm{II})$ and $\mathrm{Cu}(\mathrm{II})$ Complexes with 2-Formilpyridine N(4)-Phenylthiosemicarbazone. Polyhedron, 97, 157-166. https://doi.org/10.1016/j.poly.2015.05.009

[31] Muralisankar, M., Sujith, S., Bhuvanesh, N.S.P. and Sreekanth, A. (2016) Synthesis and Crystal Structure of New Monometallic and Bimetallic Copper(II) Complexes with N-Substituted Isatin Thiosemicarbazone Ligands: Effects of the Complexes on DNA/Protein-Binding Property, DNA Cleavage Study and in Vitro Anticancer Ac- 
tivity. Polyhedron, 118, 103-117. https://doi.org/10.1016/j.poly.2016.06.017

[32] Sreekanth, A. and Prathapachandra Karup, M.R. (2003) Structural and Spectral Studies on Four Coordinate Copper(II) Complexes of 2-Benzoylpyridine N(4), N(4)-(butane-1,4-diyl) Thiosemicarbazone. Polyhedron, 22, 3321-3332. https://doi.org/10.1016/j.poly.2003.07.011 